Urgensi Pengembangan Kurikulum Pesantren dalam Meningkatkan Mutu Pendidikan

\title{
URGENSI PENGEMBANGAN KURIKULUM PESANTREN DALAM MENINGKATKAN MUTU PENDIDIKAN
}

\author{
Asnawan \\ Dosen IAI Al Falah As Sunniyyah Kencong Jember \\ email: asnawanwan@gmail.com
}

\begin{abstract}
Curriculum development can be done using several approaches. According to Soetopo, there are two types of approaches that can be taken in developing the curriculum, namely the approach that is rooted in the subject matter and approaches that are rooted in the teaching objectives. The first approach is the material-oriented approach to the course. In this approach, the first question arises when compiling a curriculum is what material or material needs to be taught to students. While Hamalik categorizes the curriculum development management approach in six approaches to curriculum development management activities.
\end{abstract}

Keywords: Curriculum Development, Islamic Boarding School, Quality of Education

\section{PENDAHULUAN}

Perkembangan sains dan teknologi serta arus informasi di era globalisasi menuntut semua bidang kehidupan untuk beradaptasi agar tetap relevan dengan perkembangan zaman. Adaptasi tersebut secara langsung mengubah tatanan dalam sistem mikro, meso, maupun makro, tidak terkecuali sistem pendidikan termasuk sistem pendidikan pesantren. Untuk itu, sistem pendidikan harus dikembangkan sesuai dengan kebutuhan dan perkembangan yang terjadi baik di tingkat lokal, nasional, maupun global. Salah satu komponen penting dari sistem pendidikan tersebut adalah kurikulum, karena merupakan komponen yang dijadikan acuan pada satuan pendidikan.

Kurikulum dalam pendidikan menempati posisi yang strategis, dan merupakan landasan yang dijadikan pedoman bagi pengembangan kemampuan peserta didik/santri secara optimal sesuai dengan perkembangan masyarakat. ${ }^{1}$ Untuk kepentingan itu, kurikulum harus dirancang secara terpadu sesuai dengan aspek-aspek kurikulum guna mencapai tujuan pendidikan yang diharapkan. Di samping itu, disusun dan dikembangkan dengan melibatkan berbagai komponen

\footnotetext{
${ }^{1}$ Pengembangan dan pelaksanaan kurikulum untuk dapat mengoptimalkan hasil sesuai kondisi yang ada untuk mencapai tujuan yang dicita-citakan oleh siswa, keluarga, maupun masyarakat. Lihat Nana Saodih Sukmodinoto, Pengembangan Kurikulum Teori dan Praktek (Bandung: Remaja Rosdakarya), hlm. 12
}

Falasifa, Vol. 9 Nomor 2 September 2018 | 135 


\section{Asnawan}

yang tidak hanya menuntut ketrampilan teknis, tetapi harus memperhatikan berbagai faktor yang mempengaruhinya. ${ }^{2}$ Namun demikian, kurikulum seringkali tidak mampu mengikuti kecepatan laju perkembangan masyarakat. Oleh karena itu, pembenahan dan pengembangan kurikulum harus senantiasa dilakukan secara berkesinambungan untuk memenuhi kebutuhan masyarakat dan tuntutan zaman.

Menurut Nurcholish Madjid, istilah kurikulum sebenarnya tidak dikenal di dunia pesantren, terutama masa prakemerdekaan, walaupun sebenarnya materi pendidikan dan keterampilan sudah ada dan diajarkan di pesantren. Kebanyakan pesantren tidak merumuskan dasar dan tujuan pesantren secara eksplisit dalam bentuk kurikulum, bahkan tujuan pendidikan pesantren ditentukan oleh kebijakan kiai, sesuai dengan perkembangan pesantren tersebut. ${ }^{3}$

Dalam perkembangannya, setiap pesantren memiliki ciri khas masingmasing disertai dengan corak pendidikannya yang bermacam-macam. Pesantren besar, seperti Pesantren Modern Darussalam Gontor Ponorogo, Darun Najah dan Darur Rahman Jakarta, Pesantren Tebuireng Jombang, Pesantren Nurul Jadid Paiton, Pesantren Zainul Hasan Probolinggo dan Salafiyah Syafi'iyah Sekorejo Situbondo, Pesantren Al-Qodiri Jemberdan pesantren pesantren besar lainnya di dalamnya telah berkembang madrasah, sekolah umum, sampai perguruan tinggi. Demikian pula pesantren mahasiswa Al-Hikam dan ma'bad yang ada di UIN Malang yang dalam proses pencapaian tujuan institusionalnyatelah menggunakan kurikulum secara baik.

Dalam implementasinya terdapat persamaan dan perbedaan pada pengembangan kurikulum yang dilakukan oleh model pesantren salaf, khalaf dan pesantren kombinasi, bahkan pesantren mahasiswa. Hanya saja beberapa pesantren yang mengikuti pola salafiyyah (tradisional),kurikulumnya belum dirumuskan secara baik.Sebagai lembaga pendidikan non-formal, kurikulum pesantrensalaf memiliki spesifikasi keilmuan dengan mempelajari kitab-kitab klasikmeliputi: Tauhid, Tafsir, Hadits, Fiqh, Ushul Fiqh, Tasawwuf, Bahasa Arab (Nahwu, Sharaf, Balaghah dan Tajwid), Mantiq dan Akhlak. Pelaksanaan kurikulum pendidikan pesantren salaf berdasarkan kemudahan dan kompleksitas ilmu atau masalah yang dibahas dalam kitab. Jadi, ada tingkat awal, menengah dan tingkat lanjutan.

Gambaran kurikulum yang harus dibaca dan dipelajari oleh santri, menurut Zamakhsyari Dhofier mencakup kelompok ilmu "Nahwu dan Sharaf, Ushul Fiqh, Hadits, Tafsir, Tauhid, Tasawwuf, cabang-cabang yang lain seperti Tarikh dan

${ }_{2}^{2}$ John dan Joseph Bondi, Curuculum Development, A Guide to Practice, (Ohio: Merryl Publihing Company, 1989), hlm. 13

${ }^{3}$ Nurcholish Madjid, Bilik-Bilik Pesantren Sebuah Potret Perjalanan (Jakarta: Paramadina, 1997), hlm. 59.

136 | FALASIFA, Vol. 9 Nomor 2 September 2018 
Balaghah".

Itulah gambaran sekilas isi kurikulum pesantren salaf secara umum bersumberkan dari kitab-kitab klasik, disertai pemberian keterampilan yang bersifat pragmatis dan sederhana bagi para santri.Adapun karakteristik kurikulum yang ada pada pesantren modern mulai diadaptasikan dengan kurikulum pendidikan Islam yang disponsori oleh Departemen Agama melalui sekolah formal (madrasah). Kurikulum khusus pesantren tersebut dialokasikan dalam muatan lokal atau diterapkan melalui kebijaksanaan sendiri.Gambaran kurikulum lainnya adalah pada pembagian waktu belajar, yaitu mereka belajar keilmuan sesuai dengan kurikulum yang ada di perguruan tinggi (sekolah) pada waktu-waktu kuliah. Waktu selebihnya dengan jam pelajaran yang padat dari pagi sampai malamuntuk mengkaji ilmu Islam khas pesantren (pengajian kitab klasik). ${ }^{5}$

Fenomena pesantren saat ini yang mengadopsi pengetahuan umum untuk para santrinya, tetapi masih tetap mempertahankan pengajaran kitab-kitab klasik merupakan upaya untuk meneruskan tujuan utama lembaga pendidikan tersebut, yaitu pendidikan calon ulama yang setia kepada paham Islam tradisional. ${ }^{6}$ Kurikulum pendidikan pesantren modern termasuk pesantren mahasiswamerupakan perpaduan antara pesantren salaf dan sekolah (perguruan tinggi),diharapkan akan mampu memunculkan out-put pesantren berkualitas yang tercermin dalam sikap aspiratif, progresif dan tidak "ortodoks" sehingga santri bisa secara cepat beradaptasi dalam setiap bentuk perubahan peradaban dan bisa diterima dengan baik oleh masyarakat sekitarnya karena mereka bukan golongan eksklusif, dan memiliki kemampuan yang siap pakai.

\section{PEMBAHASAN}

\section{Tipologi Pesantren dan Kurikulum Pesantren}

Pengertian pesantren, secara sederhana, dikemukakan oleh Zamahsyari Dhofierdalam bukunya yang berjudul Tradisi Pesantren. Ia mendefinisikan pesantren sebagai lembaga pendidikan tradisional Islam untuk mempelajari, memahami, menghayati dan mengamalkan ajaran Islam dengan menekankan pentingnya moral keagamaan sebagai pedoman perilaku sehari-hari. ${ }^{7}$ Sistem

${ }^{4}$ Zamakhsyari Dhofier, Tradisi Pesantren (Jakarta: LP3ES, 1982), hlm. 50.

${ }^{5}$ Ainurrafiq, "Pesantren dan Pembahamaan: Arah dan Implikasi", dalam Abuddin Nata, Sejarah Pertumbuban dan Perkembangan Lembaga-Lembaga Islam di Indonesia (Jakarta: Gramedia Widiasarana Indonesia, 2001), hlm. 155.

${ }^{6}$ Imam Bawani, Tradisionalisme dalam Pendidikan Islam (Surabaya: al-Ikhlas, 1998), hlm. 95-96.

${ }^{7}$ ZamahsyariDhofier, TradisiPesantren (Jakarta: LP3ES, 1994), hlm. 3.

FaLASIFA, Vol. 9 Nomor 2 September 2018 | 137 


\section{Asnawan}

pendidikan pesantren menggunakan pendekatan holistic, artinya para pengasuh pesantren memandang bahwa kegiatan belajar-mengajar merupakan kesatupaduan atau lebur dalam totalitas hidup sehari-hari. Bagi warga pesantren, belajar di pesantren tidak mengenal hitungan waktu, kapan harus memulai dan kapan harus selesai, dan target apa yang harus dicapai. Idealnya pengembangan kepribadian yang dituju ialah kepribadian Muslim yang kaffah, bukan sekadar Muslim biasa. ${ }^{8}$

Secara garis besar, karakter utama pesantren adalah, (1). Pesantren didirikan sebagai bagian dan atas dukungan masyarakatnya sendiri, (2). Pesantren dalam penyelenggaraan pendidikannya menerapkan kesetaraan dan kesederhanaan santrinya, tidak membedakan status dan tingkat kekayaan orang tuanya, (3).Pesantren mengembangkan misi 'menghilangkan kebodohan' khususnya tafaqquh fi al-din dan mensyiarkan agama Islam.

Adapun tipologi pesantren, menurut Zamakhsyari Dhofier, secara garis besar terbagi menjadi dua kelompok. Pertama, pesantren Salafi yang tetap mempertahankan pengajaran kitab-kitab Islam klasik sebagai inti pendidikan di pesantren tradisional. Sistem madrasah diterapkan untuk memudahkan sistem sorogan yang dipakai dalam lembaga-lembaga pengajian bentuk lama, tanpa mengenalkan pengajaran pengetahuan umum.Kedua, pesantren modern yang telah memasukkan pelajaran-pelajaran umum dalam madrasah-madrasah yang dikembangkannya, atau membuka tipe-tipe sekolah umum dalam lingkungan pesantren. Pondok pesantren Gontor tidak mengajarkan lagi kitab-kitab Islam klasik. Pesantren-pesantren besar seperti Tebuireng dan Rejoso di Jombang telah membuka SMP dan SMA dan Universitas. Sementara itu tetap mempertahankan pengajaran kitab-kitab Islam klasik. ${ }^{9}$

Pengelompokan di atas tampaknya perlu diurai lagi. Hal ini mengingat perkembangan pesantren yang sudah sangat pesat akhir-akhir ini. Ridwan Nasir mengelompokkan pesantren menjadi lima, yaitu: 1) pesantren Salaf, yaitu pesantren yang di dalamnya terdapat sistem pendidikan Salaf (weton dan sorogan) dan sistem klasikal, 2) pesantren semi berkembang, yaitu pesantren yang didalamnya terdapat sistem pendidikan Salaf (weton dan sorogan) dan sistem madrasah swasta dengan kurikulum $90 \%$ agama dan $10 \%$ umum, 3) pesantren berkembang, yaitu pondok pesantren seperti semi berkembang hanya saja lebih variatif yakni $70 \%$ agama dan $30 \%$ umum, 4) pesantren modern, yaitu seperti pesantren berkembang hanya saja sudah lebih lengkap dengan lembaga pendidikan yang ada di dalamnya sampai perguruan tinggi dan dilengkapi dengan takhasus

${ }^{8}$ Mastuhu, Dinamika Sistem Pendidikan Pesantren (Jakarta: INIS, 1994), hlm.57.

${ }^{9}$ Zamakhsyari Dhofier, Tradisi Pesantren, hlm. 41-42. 
bahasa Arab dan Inggris, dan 5) pesantren ideal, yaitu pesantren sebagaimana pesantren modern, hanya saja lembaga pendidikan yang ada lebih lengkap terutama dalam bidang keterampilan yang meliputi teknik, perikanan, pertanian, perbankan dan lainnya yang benar-benar memperhatikan kualitas dengan tidak menggeser ciri khas pesantren. ${ }^{10}$

Beberapa karakteristik pesantren di atas merupakan salah satu indikasi pesantren melakukan inovasi-inovasi untuk mengukuhkan eksistensinya. Inovasi dan pembaruan pesantren, secara umum, selalu menarik dikaji karena mengandung empat signifikansi: Pertama, kajian pembaruan pesantren dan madrasah merupakan kajian yang relevan dalam konteks keIndonesiaan yang sedang melakukan proses pembangunan dan modernisasi; kedua, pesantren merupakan subkultur pendidikan Islam Indonesia sehinggga dalam menghadapi pembaruan akan memberikan warna yang unik; ketiga, pendidikan pesantren ditengaraimerupakan prototype model pendidikan yang ideal bagi bangsa Indonesia. Karena di dalamnya menyeimbangkan antara ranah kognitif, afektif, dan psikomotorik; keempat, untuk mengamati apakah pesantren yang dikatakan sebagai lembaga pendidikan tradisional melakukan pembaruan atau tidak. ${ }^{11}$ Sampai sejauh mana pembaruan pesantren dilaksanakan agar bisa berdialektika dengan modernisasi dan dunia luar.

Agar lebih memudahkan kajian mengenai pesantren, maka poin-poin berikut ini bisa memberi penjelasan mengenai struktur dan sistem yang menopang pesantren.

\section{Tipologi Pesantren}

Secara umum tipologi pesantren dapat dibagi atas dua jenis yaitu: pesantren Salafiah, dan pesantren khalafiah. Kategori pesantren Salafiah adalah yang dikategorikan sebagai pesantren yang hanya mengajarkan pengetahuan keagamaan dan lembaga pendidikan madrasah, sedangkan pesantren khalafiah adalah yang dikategorikan sebagai pesantren modern yang selain mengajarkan pengetahuan keagamaan, madrasah, dan keterampilan praktis.

Sebagai lembaga pendidikan, dakwah, sosial, dan budaya, pesantren telah memberikan corak khas bagi arah pendidikan di nusantara. Kehadirannya mengikuti perkembangan dinamika masyarakat, ia selalu tampil untuk menjawab tantangan yang dihadapi oleh masyarakat sekitarnya, dengan demikian kehidupan

${ }^{10}$ M. Ridwan Nasir,Mencari Tipologi Format Pendidikan Ideal: Pondok Pesantren Di Tengah Arus Perubahan (Yogyakarta: Pustaka Pelajar, 2005), hlm. 87-88.

${ }^{11}$ Abuddin Nata, Kapita Selekta Pendidikan Islam (Bandung:Angkasa Bandung, 2003), hlm. 115 .

Falasifa, Vol. 9 Nomor 2 September $2018 \mid 139$ 
pesantren selalu dinamis. ${ }^{12}$

Kritik yang dialamatkan kepada pesantrenjumud, tradisionalis, dan tidak responsif-secara langsung dijawab oleh kalangan internal pesantren dengan melakukan inovasi di beberapa bidang, misalnya dalam segi metode pengajaran, kurikulum, hingga manajemen pengelolaan pesantren. Inovasi-inovasi ini dijalankan oleh kalangan pesantren secara evolutif, sehingga membuat pesantren tetap bertahan sebagai bagian integral tradisi Islam Indonesia, dan bercorak pewaris tradisi indegenous Islam Indonesia. Keberhasilan pesantren mempertahankan diri di tengah kemajuan zaman, di antaranya, dengan mengaplikasikan sebuah kaidah al-Muhafadhat 'ala al-Qadim al-Shalih wa al-Akhdz bi al-Jadid al-Ashlahyang secara bebas dimaknai sebagai upaya "menjaga sesuatu yang lama (klasik) yang positif, sambil mengadopsi sesuatu yang baru yang lebih aktual dan positif'.

Pengaplikasian kaidah di atas merupakan sebuah implementasi ruang dinamis pesantren. Di satu sisi, sebagai lembaga pendidikan Islam, pesantren dengan kukuh menjaga dan melestarikan warisan klasik (al-turats al-qadim) berupa khazanah keilmuan Islam zaman keemasan yang lazim disebut "kitab kuning". Di sisi yang lain, pesantren tidak bisa menghindari perubahan dan kemajuan zaman sebagai akibat dari modernisasi. Dengan kata lain, meminjam istilah Abid al-Jabiri, pesantren berada dalam wilayah tarik menarik antara periode klasik (al-turats) dan modernitas (al-hadatsah). ${ }^{13}$ Dalam wilayah ini, pengasuh pesantren akan selalu dihadapkan pada pilihan "mendua", dalam tradisionalitas yang melestarikan warisan lama sebagai konsekuensi ideologis ahl al-sunnah wa al-jama'ah, dengan tantangan modernitas sebagai tuntutan sosial-historis.

Dengan demikian, pesantren sering dikonotasikan sebagai sebuah lembaga tradisional yang berusaha menempatkan diri dalam iklim modernitas sembari mempertahankan identitasnya.

Karena itu, meskipun kemudian terdapat dikotomi pendidikan umum dan agama, pesantren tetap mampu bertahan sembari melakukan inovasi di berbagai bidang. Sebagaimana diketahui, setelah memberlakukan politik etis, pemerintah kolonial Hindia Belanda memberlakukan Ordonantie Guru dan Sekolah Umum yang secara otomatis membatasi peranan guru dalam hal belajar mengajar dan secara langsung memberi dampak siginifkan dalam hal polarisasi dan dikotomi

\footnotetext{
${ }^{12}$ Hasan, Karakter \& Fungsi Pesantren. Dalam Dinamika Pesantren (Jakarta : P3M,1988), hlm.49.

${ }^{13}$ Konsep Abid al-Jabiri ini bisa dicermati dalam karyanya, al-Turats wa al-Hadatsah: Dirasat wa al-Munaqasat (t.tp: al-Markaz al-Thaqafi al'Arabi, tt).
} 
lembaga pendidikan.

Ordonansi guru dikenal pada masa pemerintah Belanda dengan mengeluarkan peraturan yang dapat memberantas dan menutup madrasah dan sekolah yang tidak ada izinnya atau memberikan pelajaran yang tidak disukai oleh pemerintah yang disebut Ordonansi Sekolah Liar (Wilde School Ordonantie). Ordonansi guru ini menurut Nurhayati Djamas dalam Dinamika Pendidikan di Indonesia Pasca Kemerdekaan merupakan bentuk kekhawatiran pemerintah belanda terhadap penyelanggaraan pendidikan Islam dan sepak terjang guru agama yang akan memperluas pengembangan agama Islam melalui pendidikan. ${ }^{14}$

Selain itu untuk lingkungan kehidupan agama Kristen di Indonesia yang selalu menghadapi reaksi dari rakyat, dan untuk menjaga sekolah umum yang kebanyakan muridnya beragama Islam, maka pemerintah mengeluarkan peraturan yang disebut netral agama. Seperti yang dinyatakan pada Indische Staatsregeling bahwa pendidikan umum adalah netral, yang berarti pengajaran diberikan dengan menghormati keyakinan masing-masing. Namun disekolah umum untuk kalangan pribumi, pada HIS dan MULO diberikan pelajaran agama Islam, secara sukarela sekali dalam seminggu bagi murid-murid yang berminat atas persetujuan orang tuanya. Pemerintah Belanda sendiri yang melakukan pengawasan terhadap penyelenggaraan pendidikan bagi pribumi, membentuk dua lembaga, yaitu Departemen van Onderwijst en Eerendinst untuk mengawasi pengajaran agama di sekolah umum dan Departemen van Binnenlandsche Zaken untuk pendidikan Islam dilembaga pendidikan Islam.

Kebijakan pemerintah kolonial yang memarjinalkan aspirasi dan kepentingan kalangan muslim menjadi cikal bakal terciptanya dualitas pengaturan negara terhadap berbagai masalah yang berhubungan dengan kepentingan kalangan muslim. ${ }^{15}$ Langkah perubahan melalui pendidikan pada akhirnya menjadi pilihan bagi umat Islam Indonesia untuk melakukan berbagai pembaruan di berbagai bidang kehidupan dalam Islam. ${ }^{16}$

\footnotetext{
${ }^{14}$ Nurhayati Djamas, Dinamika Pendidikan di Indonesia Pasca Kemerdekaan (Jakarta: RajaGrafndo, 2009), hlm. 178.

${ }^{15}$ Nurhayati Djamas, Dinamika Pendidikan di Indonesia Pasca Kemerdekaan, hlm. 178.

${ }^{16}$ Islam lebih diidentikkan dengan Timur Tengah, hal ini karena agama Islam bermula dari daerah tersebut. Pandangan tersebut berakibat adanya pengabaian secara tidak langsung terhadap perkembangan Islam di luar Timur Tengah. Sebagai misal daerah di luar Timur Tengah adalah Indonesia. Indonesia merupakan negara yang mempunyai pemeluk Islam terbanyak di dunia. Akan tetapi hal itu berubah seiring adanya transformasi budaya dan sosial yang ada di tengah masyarakat Islam, terutama melalui jalur pendidikan.
}

FalasIfa, Vol. 9 Nomor 2 September 2018 | 141 
Demikian juga dengan bangsa Indonesia yang selama masa penjajahan terpuruk di segala bidang, akan tetapi bangsa Indonesia bangkit kembali akibat proses pendidikan yang mereka terima. Kebangkitan tersebut meliputi perkembangan rasa kebangsaan hingga perkembangan dunia pendidikan di Indonesia, yang termasuk di dalamnya adalah pendidikan Islam. Pendidikan Islam pun mengalami pembaruan. Hal ini tidak lepas dari keinginan para sarjana Indonesia untuk melakukan pembaruan di dunia pendidikan Islam.

Pembaruan-pembaruan yang juga menimpa pesantren di antaranya untuk mengimbangi polarisasi dan dikotomi pendidikan, yaitu pembagian pendidikan menjadi umum dan agama. Dikotomi pendidikan ini secara perlahan-lahan dikurangi dengan cara: (a) Mendirikan tempat-tempat pendidikan di mana ilmu agama dan ilmu pengetahuan umum diajarkan bersama-sama.(b) Memberikan tambahan pelajaran agama pada sekolah/ kampus umum yang sekuler.

Poin pertama bisa dipenuhi oleh kalangan pesantren dengan memberikan pelajaran berupa materi umum yang diitegrasikan di dalam kurikulum, sedangkan poin kedua dilaksanakan oleh beberapa sekolah, meskipun sejujurnya komposisi mata pelajaran Agama Islam yang diajarkan sangat tidak berimbang dengan kebutuhan sebenarnya bagi siswa.

Dari berbagai tingkat konsistensi dengan sistem lama dan keterpengaruhan oleh sistem modern, secara garis besar pondok pesantren dapat dikategorikan kedalam tiga bentuk yaitu a) pondok pesantren Salafiyah ; b)Pondok pesantren khalafiyah,danc)Pondok Pesantren campuran/kombinasi, ${ }^{17}$ serta jenis inovasi baru yang disebut sebagai pesantren mahasiswa.

a. Pesantren Salafiyah

Sesuai dengan namanya, salaf yang berarti lama, pesantren Salafiyah adalah pondok pesantren yang menyelenggarakan pembelajaran dengan pendekatan tradisional, sebagaimana yang berlangsung sejak awal pertumbuhannya. Pesantren Salafiyah adalah pesantren yang menyelenggarakan pendidikan dengan menggunakan kitab kuning dan sistem pengajaran yang ditetapkan oleh kiai atau pengasuh. $^{18}$

Perbelajaran ilmu-ilmu agama Islam dilakukan secara individu atau kelompok dengan kosentrasi pada kitab-kitab klasikberbahasa Arab. Penjenjangan tidak

Lihat Abuddin Nata, Kapita Selekta Pendidikan Islam (Bandung: Angkasa Bandung, 2003), hlm. 96.

${ }^{17}$ DepagRI Dirjen Kelembagaan Agama Islam, Pondok Pesantren dan Madrasah Diniyah Pertumbuhan Dan Perkembangannya(Jakarta, DEPAG RI, 2003), hlm. 28-30.

${ }^{18}$ Permenag Republik Indonesia Nomor 3 Tahun 2012 Tentang Pendidikan Keagamaan Islam Bab 1 Ketentuan Umum Ayat 5.

142 | FaLASIFA, Vol. 9 Nomor 2 September 2018 
didasarkan pada waktu, tetapi berdasarkan tamatnya kitab yang dipelajari. Dengan selesainya kitab tertentu, santri dapat naik jenjang dengan mempelajari kitab yang tingkat kesukarannya lebih tinggi demikian seterusnya. Pendekatan ini sejalan dengan prinsip pendidikan modern yang dikenal dengan sistem belajar tuntas.

b. Pesantren khalafiyah

Khalaf berarti 'kemudian' atau 'belakang' atau 'modern'. Sedangkan pesantren khalafiyah berarti pondok pesantren yang menyelenggarakan kegiatan pendidikan dengan pendekatan modern, melalui satuan pendidikan formal, baik madrasah (MI, MTs, MA atau MAK), maupun sekolah/kampus. Pesantren khalaf menerima hal-hal baru yang dinilai baik di samping tetap mempertahankan tradisi lama yang baik. Pesantren jenis ini mengajarkan pelajaran umum di madrasah dengan sistem klasikal dan membuka sekolah/kampus umum di lingkungan pesantren. Dengan alasan itu, maka masyarakatnya menyebutnya dengan pesantren modern atau khalafiyah. ${ }^{19}$

c. Pesantren campuran/kombinasi

Sebagian besar yang ada sekarang adalah pondok pesantren yang berada diantara rentang dua pengertian di atas. Sebagian pondok pesantren yang mengaku atau menamakan diri Salafiyah, pada umumnya juga menyelenggarakan secara klasikal dan berjenjang, walaupun tidak dengan nama madrasah atau sekolah/kampus.Demikian juga pesantren khalafiyahyang pada umumnya juga menyelenggarakan pendidikan dengan pendekatan pengajian kitab klasik, karena sistem ngaji kitabitulah yang selama ini diakui sebagai salah satu indentitas pondok pesantren.

Ditinjau dari model mengelola pesantren, Mastuhu mengatakan bahwa model pengelolaan pesantren dapat dibedakan menjadi dua golongan, yaitu:

Pertama, pesantren pribadi. Dalam pengelolaan pesantren pribadi, pemiliknya memiliki kebebasan menentukan jalan hidupnya sendiri dan bebas merencanakan pola pengembangannya. Hanya saja, karena otoritasnya ada di tangan satu orang, maka dalam hal kemampuan manajerial pesantren jenis ini akan sulit berkompromi dengan ide-ide baru yang datang dari luar, kecuali pengasuhnya memiliki sikap terbuka menerima hal-hal yang baru.

Kedua, Institusional. Berbeda dengan "pesantren pribadi", pesantren institusional tidak tergantung pada perorangan, tetapi dikelola secara kolektifinstitusional, lengkap dengan mekanisme sistemnya, sehingga dapat dikontrol dan dievaluasi kemajuan dan kemundurannya dengan menggunakan tolok ukur yang

\footnotetext{
${ }^{19}$ Yasmadi, Modernisasi Pesantren: Kritik Nurcholis Madjid Terbadap Pendidikan Islam Tradisional (Jakarta: Ciputat Press, 2005), hlm.70.
}

Falasifa, Vol. 9 Nomor 2 September $2018 \mid 143$ 


\section{Asnawan}

objektif. Akan tetapi, karena dikelola secara kolektif, maka seringkali pesantren jenis ini terbelenggu dengan aturan-aturan birokrasi sehingga tidak lincah dalam mengambil keputusan yang dapat menghambat kemajuan.

Namun demikian, secara keseluruhan, baik pengelolaan pesantren pribadi maupun institusi, kiai tetap merupakan tokoh kunci, dan keturunannya memiliki peluang besar menjadi penggantinya untuk memimpin pondok pesantren.

Dari dua model pengelolaan pondok pesantren di atas, agar berjalan sesuai dengan yang diharapkan maka pesantren harus menetapkan visi dan misi, tujuan dan program-programnya secara jelas dan terarah.

Ditinjau dari sudut administrasi ada 4 (empat) kategori pondok pesantren yaitu:

1) Pesantren dengan sistem pendidikan lama yang pada umumnya terdapat jauh di luar kota, dan hanya memberi pengajian kepada para santri maupun masyarakat sekitar.

2) Pesantren modern dengan sistem pendidikan klasikal berdasarkan kurikulum yang tersusun baik, termasuk pendidikan skill dan vocational (ketrampilan).

3) Pesantren dengan sistem kombinasi yang selain menyediakan pengajaran dalam bentuk pengajian juga menyediakan madrasah yang dilengkapi dengan pengetahuan umum menurut tingkatannya (klasikal).

4) Pondok pesantren di mana santri-santrinya kebanyakan belajar di sekolah/kampus di luar pesantren yang bersangkutan, sedangkan di dalam pondok sendiri tidak diwajibkan untuk mengikuti pengajian-pengajian yang diadakan oleh kiai .

Sedangkan menurut Jamal Ma'mur ${ }^{20}$ klasifikasi pesantren dibedakan menjadi tiga bentuk:

a) Pesantren Salaf, seperti al-Anwar Sarang Rembang, Pacul Gowang Jombang, dan Lirboyo-Ploso Kediri. Pesantren model ini mempunyai beberapa karakteristik di antaranya pengajian hanya terbatas pada kitab kuning (Salaf), intensifikasi musyawarah atau bahtsul masail, serta berlakunya sistem diniyah (klasikal). Sedangkan pakaian, tempat dan lingkungannya mencerminkan masa lalu, seperti kemana-mana selalu memakai sarung, songkok, dan menanamkan kemandirian seperti mencuci dan memasak sendiri.

b) Ada bebarapa kelebihan dari pesantren model ini, yaitu semangat mengarungi hidup yang luar biasa, mental kemandirian yang tinggi, terjaga moralitas dan mentalitasnya dari virus modernitas, serta mampu menciptakan insan dina-

${ }^{20}$ Fanani dan Elly (ed),Menggagas Pesantren Masa Depan: Geliat Suara Santri Untuk Indonesia Barn (Yogyakarta: Qirtas, 2003), hlm.49.

144 | FaLASIFA, Vol. 9 Nomor 2 September 2018 
Urgensi Pengembangan Kurikulum Pesantren dalam Meningkatkan Mutu Pendidikan

mis, kreatif dan progresif. Selain itu, watak kemandirian dan karakter yang tertempa di pesantren ini akan menyebabkan santri tertantang menghadapi hidup tanpa formalitas ijazah dan membuat mereka berpikir kreatif mewujudkan cita-citanya.

c) Pesantren modern, seperti Pesantren Modern Darussalam Gontor Ponorogo, maupun Darun Najah dan Darur Rahman Jakarta. Karakteristik pesantren model ini adalah penekanan pada penguasaan bahasa asing (Arab dan Inggris), tidak ada pengajian kitab-kitab kuning (Salaf), kurikulumnya mengadopsi kurikulum modern, lenturnya term-term yang berakar dari tasawuf (tawadhu, zuhud, qana'ah, barakah, dan sejenisnya), dan penekanan pada rasionalitas, orientasi masa depan, persaingan hidup dan penguasaan teknologi. Adapun kelemahan pesantren model ini adalah lemah dalam penguasaan khazanah klasik, bahkan mayoritas out putpesantren ini tidak mampu membaca kitab kuning dengan standar pesantren Salaf seperti penguasaan nahwu, sharaf, balaghah, arudh, mantiq, dan qawa'id.

d) Pesantren semi Salaf-semi modern, seperti Pesantren Tebuireng, Sunan Drajat Lamongan, dan Mathaliul Falah Kajen Pati. Karakteristik pesantren model ini adalah pengajian kitab Salaf (sepertiTaqrib, Jurumiyah, Ta'lim muta'alim, dll), ada kurikulum modern (seperti bahasa Inggris, fisika, matematika, manajemen dan sebagainya), mempunyai independensi dalam menentukan arah dan kebijakan, ada ruang kreatifitas yang terbuka lebar untuk para santri (seperti berorganisasi, membuat buletin, majalah, mengadakan seminar, diskusi, bedah buku, dll). Adapun kelemahan pesantren model ini adalah santri kurang menguasai secara mendalam terhadap khazanah klasik, bergesernya keyakinan terhadap konsep barakah, sikap tawadhu, doktrin kualat dan sikap zuhud, serta orientasi ukhurawi dan perjuangan kepada masyarakat menjadi berkurang.

\section{Kurikulum Pesantren}

Kata kurikulum, berasal dari bahasa latin (Yunani), yakni cucere yang berubah menjadi kata benda curriculum. Kurikulum, jamaknya curicula, yang pertama kali dipakai dalam dunia atlantik. Kurikulum dalam arti sempit adalah " a course, esp a specific fixed course of study, as in school or college, as one leading to a degree. ${ }^{21 "}$ kurikulum adalah sejumlah mata pelajaran di sekolah/kampus atau di perguruan tinggi yang harus di tempuh untuk mendapatkan ijazah atau naik tingkat.

\footnotetext{
${ }^{21}$ S.Nasution, Asas-Asas Kurikulum (Jakarta: Gramedia, 1982), hlm.7.
} 
Kurikulum secara umum adalah rangkaian semua program kegiatan yang telah direncanakan dan diterapkan oleh masing- masing lembaga pendidikan baik sekolah dasar, menegah, maupun perguruan tinggi. Pada pengertian yang bersifat makro ini maka kurikulum tidak hanya berbentuk draf mata pelajaran/mata kuliah yang kemudian disajikan kepada peserta didik atau mahasiswa, melainkan semua aktivitas dalam pendidikan bisa disebut sebagai kurikulum yang harus memuat sejumlah sistem yang saling mempengaruhi antara satu dengan yang lainya, misalnya kurikulum KTSP dan Kurikulum 13 (K13) yang menekankan peserta didik yang aktif.

Dengan demikian, pada tahapan ini kegiatan pembelajarannya harus bersifat student orented, kemudian sarana apa saya yang dibutuhkan dalam pengajaran terkait dengan kurikulum tersebut untuk mencapai sebuah cita-cita ideal yang diinginkan. Tujuan pendidikan dan tujuan institusi/lembaga pendidikan serta komponen sistem yang disebutkan di atas semuanya bermakna kurikulum. Dengan demikian kurikulum tidak hanya difahami sebagai draf mata kuliah/silabus tapi lebih dari itu kurikulum adalah aktivitas kegiatan, yang ada dalam kelas/luar kelas. Hal ini sesuai dengan apa yang di kemukakan oleh Robert Zaiz "curriculum is a resourse of subject matters to be mastered" ${ }^{22}$ atau kurikulum adalah serangkaian mata pelajaran yang harus dikuasai.

Sedangkan Ronald Doll mengemukakan bahwa kurikulum adalah All the experiences which are offered to learnes under the auspices or direction of the school $^{23}$ atau kurikulum adalah semua pengalaman yang disajikan kepada murid di bawah naungan atau bimbingan sekolah/kampus.

Sedangkan William B. Ragan mengartikan kurikulum sebagai the experiences of childler for which the school accepts respobility atau kurikulum adalah segala pengalaman murid di bawah naungan tanggung jawab sekolah/kampus.Sementra Oemar Hamalik ${ }^{24}$ mengatakan bahwa istilah kurikulum memiliki berbagai tafsiran yang dirumuskan oleh para pakar. Secara etimologi "kurikulum" berasal dari kata latin "curriculae", artinya jarak yang harus ditempuh oleh seorang pelari.

Pada pemahamankurikulum konvensional berarti sejumlah mata pelajaran dan jangka waktu pendidikan yang harus ditempuh oleh peserta didik maupun mahasiswa yang bertujuan untuk memperoleh ijazah. Sementara para ahli yang

\footnotetext{
${ }^{22}$ Robert S Zaiz,Curricumm Principles and Fundation (Harper \& Row Publisher: 1976), hlm.7l.

${ }^{23}$ William B. Ragan, Modern Elementry Curriculum (Holt Renehart and Winston Inc: 1960), hlm.4.

${ }^{24}$ Oemar Hamalik, Kurikulum dan Pembelajaran (Jakarta: PT Bumi Aksara, 1994), hlm.16.
}

146 | FALASIFA, Vol. 9 Nomor 2 September 2018 
lain memberikan konsep pemahamana kurikulum yang modern adalah kurikulum yang menekankan pada seluruh pengalaman belajar peserta didik.

Dalam konteks pendidikan tinggi, kurikulum adalah suatu program pendidikan yang disediakan untuk membelajarkan mahasiswa sehingga terjadi perubahan dan perkembangan tingkah laku mahasiswa, sesuai dengan tujuan pendidikan dan pembelajaran. Dengan kata lain kampus menyediakan lingkungan bagi mahasiswa yang memberikan kesempatan belajar. Itu sebabnya kurikulum harus disusun sedemikian rupa agar maksud tersebut dapat tercapai dengan baik.Kurikulum tidak terbatas pada sejumlah mata kuliah saja, melainkan meliputi semua yang dapat memberikan perkembangan bagi mahasiswa seperti gedung kampus, alat pelajaran, perlengkapan, dan semua fasilitas yang membuka kemungkinan belajar secara efektif. Semua yang berkenaan dengan perkembangan mahasiswa harus direncanakan melalui kurikulum, sebagaimana yang dikemukakan oleh Oemar Hamalik mengutip Douglass:

The curriculum is as broad and varied as the clid's school environment. Broadly conceived the curriculum embraces not only subject matter but also various of the physical and social environment. The school brings the with his impelling flow of experiences into an envirinment consisting of school facilities. Subject metter, other clildren, and teachers. From interaction or the child with these elements learning results. ${ }^{25}$

Dari dua pendapat di atas ternyata kurikulum memiliki pengertian yang begitu luas. Hal ini sebagaimana yang dikatakan oleh Kelly bahwa:

From much of what follows in this book it will be clear that the term 'curriculum' can be, and is, used, for many different kinds of programme of teaching and instruction. Indeed, as we shall see, quite often thus leads to a limited concept of the curriculum, defined interms of what teaching and instruction is to be offered and sometimes also what its purposes, its objectives, are. Hence we see statements of the curriculum for the teaching of the most basic courses in many different contexts. And we shall also see that much of the advice which has been offered for curriculum planning is effertive only at the most simplistic levels, for teaching of a largely unsophisticated and usually unproblematic kind. ${ }^{26}$

Apa yang dikemukakan oleh Kelly dapat menambah wawasan bahwa kurikulum begitu luas tidak saja menyangkut guru/dosen dan siswa/mahasiswa saja, tetapi lebih luas menyangkut manajemen. Dari beberapa pendapat para ahli

\footnotetext{
${ }^{25}$ Oemar Hamalik, Kurikulum dan Pembelajaran,....hlm.17.

${ }^{26}$ A.V.Kelly, The Curriculum Theory and Practice(London: Sage Publications. 2004), hlm.2.
}

Falasifa, Vol. 9 Nomor 2 September 2018 | 147 
tersebut sebetulnya kurikulum dapat dibedakan menjadi beberapa sudut pandang.Ada yang disebut kurikulum sebagai produk, sebagai program, sebagai hal yang diharapkan, dan sebagai pengalaman mahasiswa.

Pendidikan, kurikulum, dan pengajaran merupakan tiga konsep yang saling terkait satu sama lain. Pendidikan dimaknai sebagai usaha dan kegiatan manusia dewasa terhadap manusia yang belum dewasa, bertujuan untuk menggali potensipotensi tersebut menjadi aktual. Dengan begitu, pendidikan adalah alat untuk memberikan rangsangan agar potensi-potensi manusia tersebut dapat berkembang sesuai dengan dengan apa yang diharapkan.

Dengan perkembangan itulah maka manusia akan menjadi manusia dalam arti yang sebenarnya. Di sinilah kemudian sering diartikan sebagai upaya manusia untuk memanusiakan manusia. ${ }^{27}$ Kurikulum berfungsi untuk membina dan mengembangkan Mahasiswa menjadi manusia yang berilmu (kemampuan intelektual tinggi/cerdas), bermoral (memahami dan memiliki nilai-nilai sosial dan nilai-nilai religi) sebagai pedoman dalam hidupnya, dan beramal menggunakan ilmu yang dimilikinya untuk kepentingan manusia dan masyarakat sesuai fungsinya sebagai mahluk sosial. ${ }^{28}$

\section{KESIMPULAN}

Kegiatan manajemen pengembangan kurikulum dapat dilakukan dengan menggunakan beberapa pendekatan. Menurut Soetopo ada dua jenis pendekatan yang dapat ditempuh dalam mengembangkan kurikulum, yaitu pendekatan yang beroreantasi pada bahan-bahan mata kuliah dan pendekatan yang beroreantasi pada tujuan pengajaran.Pendekatan pertama, yaitu pendekatan yang berorientasi pada bahan mata kuliah. Dalam pendekatan ini, pertanyaan yang pertama timbul pada waktu menyusun kurikulum adalah bahan atau materi apakah yang perlu diajarkan pada mahasiswa.Sedangkan Hamalik mengkategorikan pendekatan manajemen pengembangan kurikulum dalam enam pendekatan kegiatan manajemen pengembangan kurikulum yaitu, (a) produktif, (b) humanistik, (c) demokrasi, (d) klasik, (e) romantik, (f) modern.

1.

${ }^{27}$ A. Hamid Syarief, Pengembangan Kurikulu (Surabaya: PT Bina Ilmu, 1996), hlm.

${ }^{28}$ Nana Sudjana, Pembinaan dan Perkembangan Kurikulum di Sekolah (Jakarta: Sinar Baru, 1989), hlm.3.

148 | FALASIFA, Vol. 9 Nomor 2 September 2018 


\section{DAFTAR PUSTAKA}

Nana Saodih Sukmodinoto, Pengembangan Kurikulum Teori dan Praktek (Bandung: Remaja Rosdakarya)

John dan Joseph Bondi, Curuculum Development, A Guide to Practice, (Ohio: Merryl Publihing Company, 1989)

Nurcholish Madjid, Bilik-Bilik Pesantren Sebuah Potret Perjalanan (Jakarta: Paramadina, 1997).

Zamakhsyari Dhofier, Tradisi Pesantren (Jakarta: LP3ES, 1982).

Ainurrafiq, "Pesantren dan Pembaharuan: Arah dan Implikasi", dalam Abuddin Nata, Sejarah Pertumbuban dan Perkembangan Lembaga-Lembaga Islam di Indonesia (Jakarta: Gramedia Widiasarana Indonesia, 2001)

Imam Bawani, Tradisionalisme dalam Pendidikan Islam (Surabaya: al-Ikhlas, 1998) Mastuhu, Dinamika Sistem Pendidikan Pesantren (Jakarta: INIS, 1994)

M. Ridwan Nasir,Mencari Tipologi Format Pendidikan Ideal: Pondok Pesantren Di Tengah Arus Perubahan (Yogyakarta: Pustaka Pelajar, 2005).

Abuddin Nata, Kapita Selekta Pendidikan Islam (Bandung:Angkasa Bandung, 2003).

Hasan, Karakter \& Fungsi Pesantren. Dalam Dinamika Pesantren (Jakarta : P3M,1988)

Konsep Abid al-Jabiri ini bisa dicermati dalam karyanya, al-Turats wa al-Hadatsah: Dirasat wa al-Munaqasat (t.tp: al-Markaz al-Thaqafi al'Arabi, tt).

Nurhayati Djamas, Dinamika Pendidikan di Indonesia Pasca Kemerdekaan (Jakarta: RajaGrafndo, 2009)

Abuddin Nata, Kapita Selekta Pendidikan Islam (Bandung: Angkasa Bandung, 2003)

DepagRI Dirjen Kelembagaan Agama Islam, Pondok Pesantren dan Madrasah Diniyah Pertumbuhan Dan Perkembangannya(Jakarta, DEPAG RI, 2003)

Permenag Republik Indonesia Nomor 3 Tahun 2012 Tentang Pendidikan Keagamaan Islam Bab 1 Ketentuan Umum Ayat 5.

Yasmadi, Modernisasi Pesantren: Kritik Nurcholis Madjid Terhadap Pendidikan Islam Tradisional (Jakarta: Ciputat Press, 2005)

Fanani dan Elly (ed),Menggagas Pesantren Masa Depan: Geliat Suara Santri Untuk Indonesia Baru (Yogyakarta: Qirtas, 2003)

S.Nasution, Asas-Asas Kurikulum (Jakarta: Gramedia, 1982) 
Asnawan

Robert S Zaiz,Curricumm Principles and Fundation (Harper \& Row Publisher: 1976)

William B. Ragan, Modern Elementry Curriculum (Holt Renehart and Winston Inc: 1960)

Oemar Hamalik, Kurikulum dan Pembelajaran (Jakarta: PT Bumi Aksara, 1994)

A.V.Kelly, The Curriculum Theory and Practice(London: Sage Publications. 2004)

A. Hamid Syarief, Pengembangan Kurikulu (Surabaya: PT Bina Ilmu, 1996)

Nana Sudjana, Pembinaan dan Perkembangan Kurikulum di Sekolah (Jakarta: Sinar Baru, 1989)/

150 | FALASIFA, Vol. 9 Nomor 2 September 2018 